\title{
HUBUNGAN PERSEPSI AKSEPTOR KB DENGAN PEMILIHAN MKJP DI KELURAHAN TAHTUL YAMAN KOTA JAMBI TAHUN 2017
}

\author{
Triarsy Alami, Diniyati, Indarmien Netty \\ Poltekkes Kemenkes Jambi
}

\begin{abstract}
Abstrak
Pertumbuhan penduduk di Indonesia berkisar antara 2,15\% hingga 2,49\% per tahun. Strategi dalam pelayanan kontrasepsi yang dikembangkan saat ini adalah menggalakkan pemakaian Metode Kontrasepsi Jangka Panjang (MKJP). Menurut Data Puskesmas Tahtul Yaman Kota Jambi jumlah akseptor KB IUD sebanyak 0 akseptor, Suntik 23 akseptor, Pil 384 akseptor, Kondom 293 akseptor, Implant 54 akseptor, MOP 0 akseptor dan MOW 0 akseptor. Cara kontrasepsi yang termasuk MKJP adalah IUD, Implant, MOW, dan MOP. Berdasarkan 10 akseptor yang menggunakan kontrasepsi pil dan suntik ditanyakan pada saat pengamilan data mengatakan tidak mau menggunakan IUD karena merasa takut, disamping itu belum mendapat izin suami. Dampak pemakaian pil atau pun suntikan yang dipakai selama lebih 2 tahun akan menimbulkan tekanan darah dan kenaikan berat badan (Sulistyawati, 2013 : 56). Penelitian ini merupakan penelitian analitik dengan pendekatan cross sectional yang bertujuan untuk mengetahui hubungan persepsi akseptor KB dengan pemilihan MKJP di Kelurahan Tahtul Yaman, populasi seluruh akseptor KB di Kelurahan Tahtul Yaman sebanyak 754 akseptor, dengan jumlah sampel 90 responden dan sampel diambil dengan teknik simple random sampling. Penelitian dilakukan pada bulan Maret sampai Desember 2017 dan pengambilan sampel dilakukan pada tanggal 21 sampai 28 Agustus 2017 dengan menggunakan lembar pertanyaan (kuesioner), selanjutnya data dianalisis menggunakan analisis univariat dan bivariat. Berdasarkan hasil penelitian diketahui sebagian responden (35,56\%) menggunakan MKJP, sebagian $(64,44 \%)$ responden menggunakan Non MKJP, sebagian $(51,1 \%)$ responden memiliki persepsi kurang baik tentang pemilihan MKJP, sebagian $(48,9 \%)$ responden memiliki persepsi baik tentang pemilihan MKJP dan hasil uji statistik diketahui bahwa $p$-value $=0,000<0,05$, berarti ada hubungan yang bermakna antara persepsi dengan pemilihan MKJP. Berdasarkan hasil penelitian masih ada ibu yang belum memakai KB MKJP. Disarankan kepada Kelurahan Tahtul Yaman untuk meminta staf puskesmas memberi penyuluhan lebih jelas lagi tentang pemakaian kontrasepsi khususnya IUD, Implan, dan sterilisasi laki-laki maupun perempuan dalam rangka meningkatkan pengetahuan dan persepsi Akseptor KB dalam pemilihan MKJP.
\end{abstract}

Kata Kunci: : Persepsi, akseptor KB, pemilihan MKJP

\section{PENDAHULUAN}

Masalah terpenting yang dihadapi oleh Negara berkembang, seperti di Indonesia yaitu ledakan penduduk. Pertumbuhan penduduk di Indonesia berkisar antara $2,15 \%$ hingga $2,49 \%$ per tahun. Ledakan penduduk mengakibatkan laju pertumbuhan penduduk yang hal ini karena minimnya pengetahuan serta pola budaya pada masyarakat setempat. Untuk mengatasi permasalahan tersebut pemetintah Indonesia telah menerapkan program (KB) keluarga berencana (Arum dan Sujiatini, 2011: 3).

Program Kependudukan dan Keluarga Berencana (KKB) merupakan bagian dari pembangunan prioritas nasional dan pembangunan bidang sosial budaya dan kehidupan beragama guna meningkatkan kualitas Sumber Daya Manusia yang ditandai meningkatnya Indeks Pembangunan Manusia
(IPM) dan Indeks Pembangunan Gender (IPG), ternyata penggunaan MKJP masih rendah dibandingkan dengan metode lainnya.

Hasil SDKI 2012 menunjukkan tidak ada kenaikan yang signifikan dalam penggunaan kontrasepsi dibandingkan dengan hasil SDKI 2007. Pada tahun 2007, SDKI mencatat sebanyak 57,4\% pasangan usia subur yang menggunakan kontrasepsi modern, sedangkan SDKI 2012 mencatat angka 57,9\% atau kenaikannya hanya sebesar $0,5 \%$ selama kurang lebih 5 tahun (SDKI, 2012). Hasil SDKI 2012 mencatat persentase jumlah wanita yang sudah tidak ingin anak lagi dan atau masih ingin mempunyai anak tetapi ditunda dan tidak menggunakan salah satu metoda kontrasepsi (unmet need) sebesar 8,5\%.

Salah satu strategi dari pelaksanaan program KB sendiri tercantum dalam Rencana Pembangunan Jangka Mengenah (RPJM) tahun 2009-2015 adalah meningkatnya 
penggunaan metode kontrasepsi jangka panjang (MKJP) seperti IUD (Intra Uterine Device) atau AKDR, Implant (susuk) dan Sterilisasi (MOW, MOP) (Kemenkes RI, 2014).

Secara nasional berdasarkan data BKKBN pada bulan Januari 2017 sebanyak 34.009.816 peserta KB aktif. Apabila dilihat per mix kontrasepsi maka persentasenya adalah sebagai berikut: peserta IUD 3.813.823 (11,21\%), peserta MOW 1.215 .156 (3,57\%), peserta MOP $222.814(0,66 \%)$ peserta implant $3.817 .274(11,22 \%)$, peserta suntikan 16.301.190 $(47,93 \%)$, peserta pil $7.603 .428(22,36 \%)$, dan 1.036.131 peserta kondom (3,05\%). Sebagian besar peserta KB baru bulan Januari 2017, didominasi oleh peserta KB yang menggunakan Non Metode Kontrasepsi Jangka Panjang (Non MKJP), yaitu sebesar 73,34\% dari seluruh peserta KB baru. Sedangkan peserta KB baru yang menggunakan metode jangka panjang seperti IUD, MOW, MOP dan Implant hanya sebesar 26,66\% (BKKBN, 2017:Tabel 15).

Berdasarkan data yang diperoleh dari BKKBN Provinsi Jambi Tahun 2016 peserta KB Baru MKJP (Metode kontrasepsi Jangka Panjang) sebanyak 30.200 orang dengan rincian pengguna IUD 9.020 orang, MOW 2.040 orang, Implant 19.020 orang dan MOP 120 orang (BKKBN Provinsi Jambi, 2016).

Sebagian besar AKDR memiliki angka keberlanjutan yang tinggi antara $70 \%$ dan $90 \%$ setelah satu tahun dalam uji multisenter yang luas dan efektivitas AKDR di pengaruhi oleh karakteristik alat, keterampilan penyedia layanan, dan karakteristik pemakai seperti usia dan paritas. Sebuah studi mengenai kegagalan metode 15 negara berkembang mengungkapkan angka kegagalan AKDR tahun pertama rata-rata adalah $4,0 \%$ angka kegagalan berkisar dari 1,1\% di Maroko sampai $13 \%$ di Brazil (Wulansari dan Huriawati H, 2007:21).

Berdasarkan data BKKBN Januari 2017 Jumlah peserta KB aktif di Provinsi Jambi sebanyak 514.137, dengan jumlah pengguna IUD $24.656(4,80 \%)$, suntik 231.050 (44,94\%), peserta Pil 161.010 (31,32\%), peserta Implan $76.307(14,84 \%)$, peserta MOW 5.881 $(1,14 \%)$, peserta MOP $992(0,19 \%)$. Sedangkan jumlah peserta KB aktif di Kota Jambi sebanyak 76.536 dengan pengguna IUD $1.411(1,84 \%)$, suntik $25.077(32,76 \%)$, pil $9.755(12,74 \%)$, implan 1.271 (1,67\%), MOW 19.447 (25,41\%), MOP $91(0,11 \%)$.

Data Puskesmas Tahtul Yaman Kota Jambi jumlah akseptor KB periode Triwulan ke II 2016 jumlah pengguna IUD sebanyak 0 akseptor, Suntik 23 akseptor, Pil 384 akseptor, Kondom 293 akseptor, Implant 54 akseptor, MOP 0 akseptor dan MOW 0 akseptor dan jumlah keselurahan akseptor KB Puskesmas Tahtul Yaman adalah 754 akseptor (Dinkes Kota Jambi, 2016:2). Berdasarkan 10 akseptor yang menggunakan kontrasepsi pil dan suntik ditanyakan pada saat pengamilan data mengatakan tidak mau menggunakan IUD karena merasa takut, disamping itu belum mendapat izin suami. Dampak pemakaian pil atau pun suntikan yang dipakai selama lebih 2 tahun akan menimbulkan tekanan darah dan kenaikan berat badan (Sulistyawati, $2013: 56$ ).

Berdasarkan data Puskesmas Tahtul Yaman periode Triwulan ke II 2016 dengan pengguna KB MKJP yang lebih sedikit berjumlah 54 akseptor dibandingkan pengguna KB Non MKJP berjumlah 700 akseptor, oleh sebab itu perlu diteliti hubungan persepsi akseptor KB dengan pemilihan MKJP.

\section{METODE}

Penelitian ini bersifat analitik menggunakan rancangan cross sectional. Karena pengukuran variabel dependen dan independen dilakukan secara sekaligus dalam kurun waktu yang sama dan sifatnya sesaat pada satu waktu dan tidak diikuti dalam kurun waktu tertentu. Dalam studi ini ingin diketahui bagaimanakah hubungan persepsi aksepstor KB dengan pemilihan MKJP di Kelurahan Tahtul Yaman Kota Jambi Tahun 2017.

\section{HASIL}

\section{Gambaran Pemilihan MKJP di Kelurahan Tahtul} Yaman Kota Jambi Tahun 2017

Berdasarkan hasil penelitian dari 90 responden diketahui, yang menggunakan alat kontrasepsi suntik 1 bulan sebanyak 15 responden, suntik 3 bulan sebanyak 19 responden, pil sebanyak 24 responden, implant sebanyak 29 responden, yang menggunakan IUD 3 responden, sedangkan untuk alat kontrasepsi MOW dan MOP tidak ada akseptor yang menggunakan, dapat dilihat dari tabel 5.1 berikut :

Tabel 1

Distribusi Responden Berdasarkan Pemilihan MKJP di Kelurahan Tahtul Yaman Kota Jambi Tahun 2017 $(\mathbf{n}=90)$

\begin{tabular}{|c|c|c|c|}
\hline \multirow{2}{*}{ No } & \multirow{2}{*}{ Pemilihan Alat Kontrasepsi } & \multicolumn{2}{|c|}{ Distribusi } \\
\cline { 3 - 4 } & & $\mathbf{f}$ & $\mathbf{\%}$ \\
\hline 1 & Suntik 1 Bulan & 15 & 16,7 \\
\hline 2 & Suntik 3 Bulan & 19 & 21,1 \\
\hline 3 & Pil & 24 & 26,7 \\
\hline 4 & Implant & 29 & 32,2 \\
\hline 5 & IUD & 3 & 3,3 \\
\hline 6 & MOW & 0 & 0 \\
\hline 7 & MOP & 0 & 0 \\
\hline & Total & 90 & 100,0 \\
\hline
\end{tabular}

Gambaran Persepsi Akseptor KB yang memilih MKJP di Kelurahan Tahtul Yaman Kota Jambi Tahun 2017.

Berdasarkan analisis persepsi akseptor KB yang memilih MKJP dan Non MKJP terhadap masingmasing pertanyaan, responden memiliki jawaban yang bervariasi, untuk lebih jelasnya, distribusi frekuensi berdasarkan item pertanyaan persepsi dapat dilihat pada tabel 5.2 berikut: 
Tabel 2

Distribusi Responden Berdasarkan Persepsi Akseptor terhadap MKJP di Kelurahan Tahtul Yaman Kota Jambi Tahun 2017 $(\mathbf{n}=90)$

\begin{tabular}{|c|c|c|c|c|c|}
\hline \multirow{3}{*}{ No } & \multirow{3}{*}{ Pernyataan } & \multicolumn{4}{|c|}{ Distribusi } \\
\hline & & \multicolumn{2}{|c|}{ Baik } & \multicolumn{2}{|c|}{ Kurang Baik } \\
\hline & & $\mathbf{f}$ & $\%$ & $\mathbf{f}$ & $\%$ \\
\hline 1 & $\begin{array}{l}\text { Hanya pasangan yang tidak } \\
\text { ingin punya anak lagi yang } \\
\text { bisa memakai KB MKJP }\end{array}$ & 20 & 22,2 & 70 & 77,8 \\
\hline 2 & $\begin{array}{l}\text { Pelayanan KB MKJP yang } \\
\text { diberikan sudah baik }\end{array}$ & 28 & 31,1 & 62 & 68,9 \\
\hline 3 & $\begin{array}{l}\text { Pemakaian KB MKJP bisa } \\
\text { menimbulkan efek samping }\end{array}$ & 48 & 53,3 & 42 & 46,7 \\
\hline 4 & $\begin{array}{l}\text { Pengalaman dari tetangga } \\
\text { dapat memengaruhi untuk } \\
\text { memilih KB MKJP }\end{array}$ & 51 & 56,7 & 39 & 43,3 \\
\hline 5 & $\begin{array}{l}\text { Jarak dari rumah ke tempat } \\
\text { pelayanan bisa memengaruhi } \\
\text { menggunakan KB MKJP }\end{array}$ & 32 & 35,6 & 58 & 64,4 \\
\hline 6 & $\begin{array}{l}\text { Suami ibu mendukung untuk } \\
\text { menggunakan alat kontrasepsi } \\
\text { MKJP }\end{array}$ & 52 & 57,8 & 38 & 42,2 \\
\hline 7 & $\begin{array}{l}\text { Tenaga kesehatan melayani } \\
\text { dengan ramah }\end{array}$ & 57 & 63,3 & 33 & 36,7 \\
\hline 8 & $\begin{array}{ll}\text { Tenaga kesehatan melayani } \\
\text { dan memberikan informasi } \\
\text { dengan jelas }\end{array}$ & 52 & 57,8 & 38 & 42,2 \\
\hline 9 & $\begin{array}{l}\text { Tenaga kesehatan tanggap } \\
\text { dalam memberikan pelayanan } \\
\text { KB }\end{array}$ & 43 & 47,8 & 47 & 52,2 \\
\hline 10 & $\begin{array}{l}\text { Tenaga kesehatan memberikan } \\
\text { penyuluhan tentang } \mathrm{KB}\end{array}$ & 40 & 44,4 & 50 & 55,6 \\
\hline 11 & $\begin{array}{l}\text { Ibu memanfaatkan pelayanan } \\
\text { KB MKJP }\end{array}$ & 32 & 35,6 & 58 & 64,4 \\
\hline 12 & $\begin{array}{l}\text { Petugas memberikan } \\
\text { kesempatan yang cukup pada } \\
\text { ibu untuk bertanya }\end{array}$ & 33 & 36,7 & 57 & 63,3 \\
\hline 13 & $\begin{array}{l}\text { Petugas memberikan jawaban } \\
\text { yang memuaskan pada ibu }\end{array}$ & 31 & 34,4 & 59 & 65,6 \\
\hline 14 & $\begin{array}{l}\text { Menggunakan KB MKJP } \\
\text { membuat ibu mendapat } \\
\text { kerugian }\end{array}$ & 59 & 65,6 & 31 & 34,4 \\
\hline 15 & $\begin{array}{l}\text { Ibu merasa takut terhadap } \\
\text { pemasangan Spiral }\end{array}$ & 51 & 56,7 & 39 & 43,3 \\
\hline 16 & $\begin{array}{l}\text { Ibu merasa takut Spiral dapat } \\
\text { menembus tempat lain } \\
\text { didalam tubuh, misalnya perut }\end{array}$ & 50 & 55,6 & 40 & 44,3 \\
\hline 17 & $\begin{array}{l}\text { Ibu malu terhadap pemasangan } \\
\text { Spiral }\end{array}$ & 47 & 52,2 & 43 & 47,8 \\
\hline 18 & $\begin{array}{l}\text { Ibu merasa takut terjadi kram } \\
\text { pada tangan saat melakukan } \\
\text { pemasangan Implant }\end{array}$ & 37 & 41,1 & 53 & 58,9 \\
\hline 19 & $\begin{array}{l}\text { Jika suami melakukan KB } \\
\text { MOP merupakan tindakan } \\
\text { yang salah }\end{array}$ & 22 & 24,4 & 68 & 75,6 \\
\hline 20 & $\begin{array}{l}\text { Ibu merasa takut melakukan } \\
\text { KB MOW }\end{array}$ & 55 & 61,1 & 35 & 38,9 \\
\hline
\end{tabular}

Hubungan Persepsi Akseptor KB dengan Pemilihan MKJP di Kelurahan Tahtul Yaman Kota Jambi Tahun 2017.

Hasil penelitian diketahui hubungan persepsi dengan pemilihan MKJP dan Non MKJP di kelurahan Tahtul Yaman kota jambi tahun 2017 sebagai berikut :
Tabel 3

Distribusi Responden Berdasarkan Hubungan Persepsi Akseptor KB dengan Pemilihan MKJP di Kelurahan Tahtul Yaman Kota Jambi Tahun 2017

\begin{tabular}{|c|c|c|c|c|c|c|c|c|}
\hline \multirow{3}{*}{ No } & \multirow{3}{*}{ Persepsi } & \multirow{2}{*}{\multicolumn{2}{|c|}{ NON MKJP }} & \multirow{2}{*}{\multicolumn{2}{|c|}{ MKJP }} & \multirow{2}{*}{\multicolumn{2}{|c|}{ Jumlah }} & \multirow{3}{*}{$\begin{array}{l}\text { p- } \\
\text { value }\end{array}$} \\
\hline & & & & & & & & \\
\hline & & Jml & $\%$ & \multicolumn{2}{|c|}{\begin{tabular}{l|l} 
Jml & $\%$
\end{tabular}} & Jml & $\%$ & \\
\hline 1 & Kurang Baik & 38 & 65,5 & 8 & 25,0 & 46 & 51,1 & \multirow{3}{*}{0,000} \\
\hline \multirow[t]{2}{*}{2} & Baik & 20 & 35,5 & 24 & 75,0 & 44 & 48,9 & \\
\hline & Total & 58 & 100,0 & 32 & 100,0 & 90 & 100,0 & \\
\hline
\end{tabular}

Tabel 3 menjelaskan bahwa hubungan persepsi dengan pemilihan MKJP dan Non MKJP di kelurahan Tahtul Yaman diketahui 58 responden dengan pemilihan Non MKJP, $38(65,5 \%)$ responden termasuk ke dalam kategori kurang baik. 32 responden pemilihan MKJP, 24 $(75,0 \%)$ responden termasuk kategori baik. Hasil uji statistik diketahui bahwa $p$-value $=0,000<0,05$, dengan kata lain ada hubungan yang bermakna antara persepsi dengan pemilihan MKJP.

\section{SIMPULAN}

Berdasarkan uraian dari hasil penelitian dan pembahasan tentang hubungan persepsi akseptor $\mathrm{KB}$ dengan pemilihan MKJP di Kelurahan Tahtul Yaman Kota Jambi tahun 2017, maka dapat disimpulkan bbahwa: Sebagian $(64,5 \%)$ responden menggunakan kontrasepsi Non MKJP dan ada sebagian kecil $(35,5 \%)$ responden yang menggunakan MKJP, Sebagian besar responden yang menggunakan MKJP mempunyai persepsi baik (75\%) dan sebagian responden Non MKJP mempunyai persepsi kurang baik $(65,5 \%)$, Terdapat hubungan yang bermakna antara persepsi dengan pemilihan MKJP dengan $p$-value $0,000<0,05$.

\section{DAFTAR PUSTAKA}

Arum, D \& Sujiatini, T. 2011. Panduan Lengkap Pelayanan KB Terkini. Nuha Medica. Yogyakarta: 224.

Panduan Lengkap Pelayanan KB Terkini. Nuha Medica. Yogyakarta: 224. Arum, D \& Supartini. 2010.

Panduan Memilih Kontrasepsi. Yogyakarta: Nuha Medica BKKBN. 2017.

Laporan Program KB Nasional Sistem Informasi Kependudukan \& Keluarga (SIDUGA).

Dinkes Provinsi Jambi. 2016. Profil Kesehatan Provinsi Jambi 2015. Jambi: Dinas Kesehatan Provinsi Jambi.

Dinkes Kota Jambi. 2016. Profil Kesehatan Kota Jambi 2015. Jambi: Dinas Kesehatan Kota Jambi.

Kemenkes RI. 2014. Profil Kesehatan Indonesia Tahun 2013. Jakarta: Kementerian Kesehatan RI.

Sulistyawati, Ari. 2012. Pelayanan Keluarga Berencana. Jakarta: Salemba Medika.

Dewi, Putri \& Notobroto, Hari. 2014 Rendahnya Keikutsertaan Pengguna Metode Kontrasepsi Jangka Panjang Pada Pasangan Usia Subur. Jurnal Biometrika dan Kependudukan, Vol.3, No.1 66-72. 
Nikmawati, Nuril. 2017. Faktor-Faktor yang Berhubungan dengan Penggunaan Metode Kontrasepsi Jangka Panjang. Jurnal Kebidanan Vol.6, No. 12 39-46

Novianti, Siti \& Gustaman, Rian. 2014. Faktor Persepsi dan Dukungan Isteri yang Berhubungan dengan Partisipasi KB Pria. Jurnal Kesehatan Komunitas Indonesia, Vol.10, No.2 1017-1026. 